\title{
Utilizing User Generated Content in the Creation of Land Ownership Boundaries for the Crofters of Scotland
}

\author{
William Mackaness, ${ }^{\mathrm{a}, \mathrm{b}}$ Rica Duchateau ${ }^{\mathrm{a}}$ \& Jamie Cross ${ }^{\mathrm{a}}$ \\ ${ }^{a}$ School of GeoSciences, The University of Edinburgh Scotland william.mackaness@ed.ac.uk \\ ${ }^{b}$ School of Social \& Political Studies, The University of Edinburgh Scotland william.mackaness@ed.ac.uk
}

\begin{abstract}
Land registration is important in land tenure security and often resolves land-related issues. Volunteered geographic information is a cheap and quick alternative to formal and traditional approaches to land registration. This research investigates the extent to which this tool is meaningful for land registration, with the Scottish crofting community as a case study. CroftCappture was developed to record points along boundaries and save geotagged photographs and descriptions. The project raised interesting questions over usability, functionality and accuracy, as well issues of privacy, crofting practices, digital competency, and highlighted the fractal nature of the digital divide.
\end{abstract}

Keywords: land registration, crofting, smartphones, volunteered geographic information

\section{Introduction}

Land registration is crucial in ensuring land tenure security and facilitating good governance, and is linked with increased land value and the stimulation of investment (Feder and Nishio, 1999; UNECE, 2005; De Vries et al., 2016). Land registration is defined as "the official, systematic process of managing information about land tenure" (Nichols, 1993, 4) and forms an essential part of land administration systems. Dysfunctional LASs lead to problems such as boundary conflicts, land degradation and land grabbing (McLaren, 2011b). In many less developed countries, LASs are not at the same standards as those in more developed countries, and for certain communities they are not even existent; this issue is known as the cadastral divide (Bennett et al., 2013). In closing the cadastral divide, highly accurate, traditional surveying methods are incompatible with the needs of less developed regions. The sheer cost and time involved to hire land professionals to generate accurate and standardised land information is a major barrier to many governments in putting such systems in place (Dale and McLaughlin, 1988; Indufor, 2014; McLaren, 2014). Cheaper, widely available tools to collect and identify spatial information, employed in a crowdsourced or volunteered geographic information context, are therefore recognised by some as a useful alternative to help put proper LASs in place (Moreri et al., 2015). This approach is termed 'fit-forpurpose', as it is seen as adequately accurate for the recordation of land tenure where LASs are incomplete (McLaren, 2011b; Moreri et al., 2016). The latest VGI tech- nique being explored for land registration is the use of smartphones, given their positioning and multimediacapturing capabilities as ubiquitous, low-cost devices. Strictly measuring boundary coordinates is usually deemed the most ac- curate and correct way of recording land tenure in the Western world, but descriptions and photographs capture addi- tional information that is otherwise lost in a purely geometrical shapefile. For instance, a description may indicate that a boundary fence is shared, something that cannot be expressed in coordinates, or it may take note of a section of a boundary that is not fixed, but instead roughly agreed upon. These 'informal' forms of tenure recordation can often underpin a more complex system of land rights (UN-Habitat, 2012). While the technology for smartphone-based VGI for land registration is in place, very little has been researched about the efficacy of this approach in recording (com- plex) cadastral information among communities (McLaren, 2013). In order to thoroughly investigate the issues sur- rounding this approach, particularly the socio-technical implications, it is necessary to observe how land registration through a smartphone-based VGI system works within a community.

One community in a more developed region with an incomplete land register is the crofting community in the Scottish Highlands and Isles. Crofters are tenants of crofts, which are agricultural units of under 50 hectares falling under specific legislation. Digital, map-based croft registration is far from complete and while a former Register of Crofts is available, it is narrative by nature, not having a spatial information component attached. Formal surveying approaches would require 20 more years to complete the register. The Crofting Commission recognises the im- portance of an up-to-date Crofting Register in providing reassurance and tenure security to crofters (especially in accessing commercial loans), so its completion is urgent (The Scottish Government, 2009).

In this research (Duchateau 2016) we sought to determine the extent to which smartphone-based volunteered geographic information can be employed for land registration? - which leads to a set of secondary questions: What is the quality of land boundary information captured using smartphones? Are individual land owners/tenants able to inde- pendently use smartphones to capture land boundary information? How 
would land owners/tenants make use of the functionality to add descriptions and take photographs to enrich evidence of their tenure over a piece of land and potentially clarify any boundary complexities? What are land owners/tenants' opinions on using smartphone-based VGI in registering their land?

\section{Methodology}

CroftCappture is an Android application developed to allow crofters to record evidence of their croft using functionality that supports: Walk-around croft boundary coordinate recording using GNSS, Geotagged photograph capture and Geotagged textual description entry (Fig 1). The focus of CroftCappture is on the user's experience when using smartphones to capture information about their land for registration purposes; CroftCappture serves as a proof-of- concept application built around usercentred design that sought to keep the application simple and straightforward to use by people with a variety of backgrounds in smartphone usage.

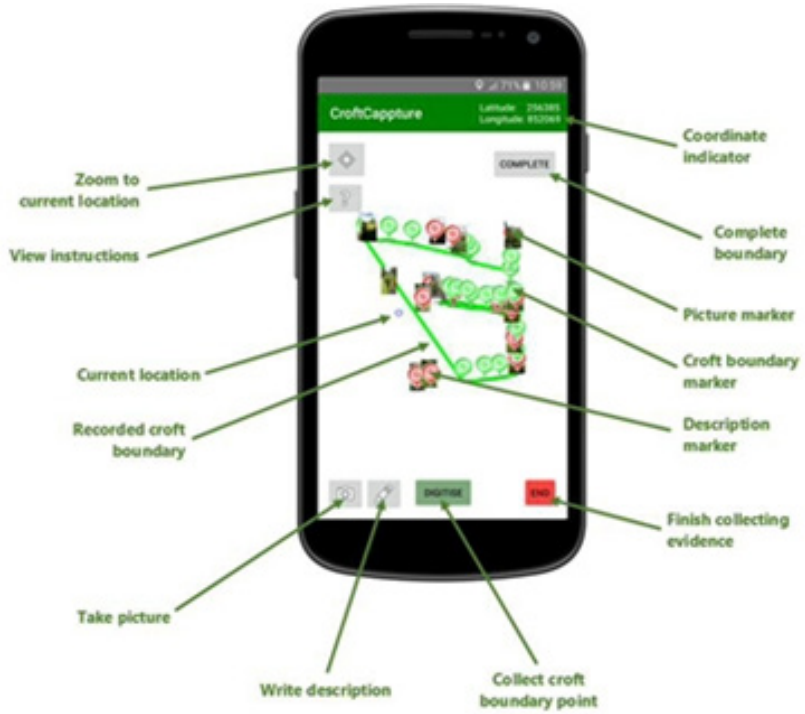

Fig 1: The evidence collection interface of CroftCappture.

The technical evaluation criteria for CroftCappture are inspired by Clegg et al. (2006) and Prastowo (2011), who list accuracy, compatibility, functionality and reliability as the criteria for evaluation. The root mean squared error of the coordinates was used to determine the accuracy of the application. The usability and functionality was tested among a small group of volunteers in a mock city environment before being tested in three crofting townships near Inverness. Only 3 individuals volunteered despite various efforts to promote the research - perhaps indicating their circumspect view of technology. Interviews happened in an unstructured manner in order to gather more detailed information (Van Elzakker, 2004).

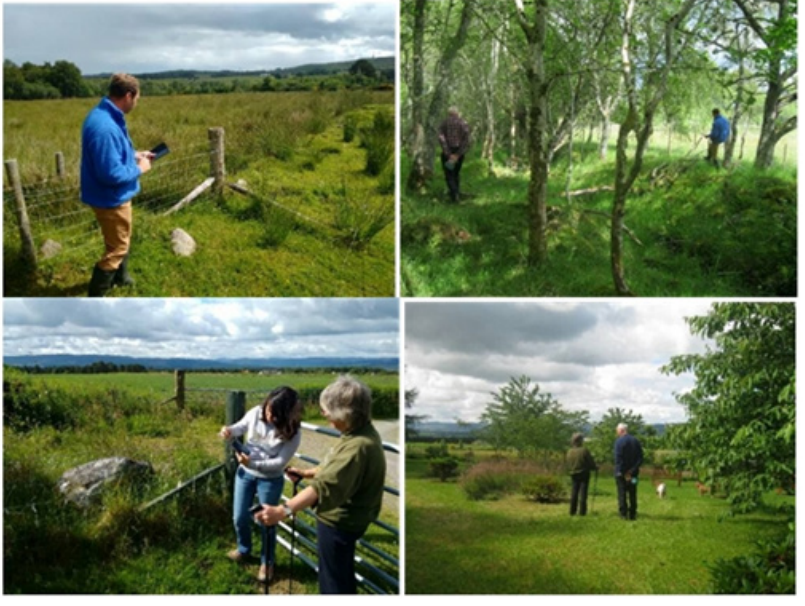

Fig 2: Field based experiments

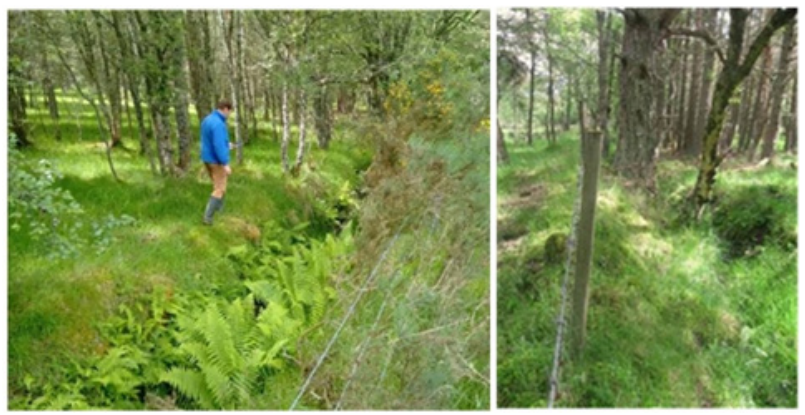

Fig 3: Left: accessibility to a boundary fence is thwarted by a deep creek. Right: the boundary sections runs straight through a forest (undetectable from aerial photographs).

\section{Results}

In controlled experiments the RMSE was calculated at $3.21 \mathrm{~m}$ (for a set of points that were readily accessible). In reality it was not always possible to precisely walk boundaries because of access difficulties or rough ground (Fig 3). Crofters vary considerably in age and exposure to technology. Some found the interface difficult to use in ambient conditions and use revealed confusion in the sequencing of operations to record boundary information and required assistance. Sometimes dialog boxes were dismissed and their content not properly understood indicating that the crofter was adopting a trial and error approach. Crofters expressed suspicion asking 'Is this device recording other things I don't know about as I walk around my fields?'. The same crofter asked if the data could be linked to his government subsidy payment (which is based on field size). Some crofters wanted to record the history and provenance of their croft and its landmarks Others adopted a more minimalist 'mark, photograph, next' approach. Some crofters thought the device was streaming coordinates whereas it required the user to decide on the frequency of point collection (itself an important accuracy issue). Access to the boundary was a problem (Fig 3); sometimes the crofter did not bother to record the exact centerline if the boundary was a fallen stone wall. Some crofters wanted to avoid recording monuments as they did not want to be responsible for their upkeep. 


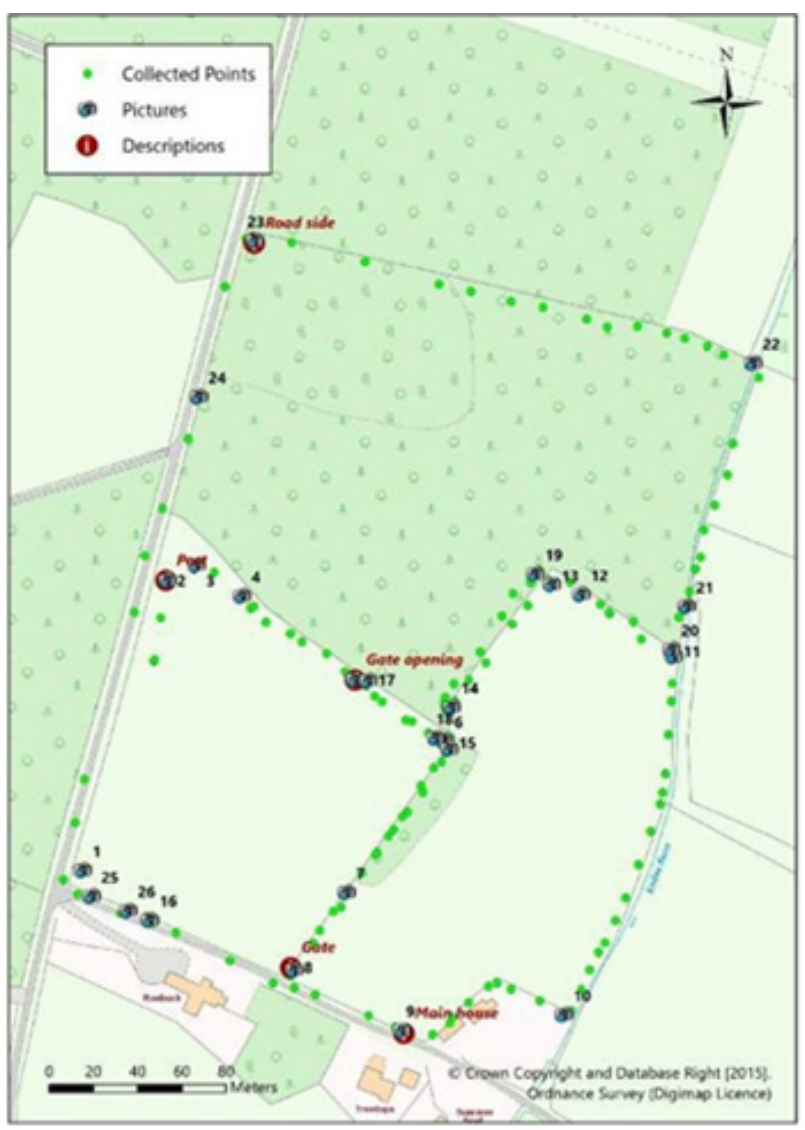

Fig 4: Comparing recorded points with MasterMap.

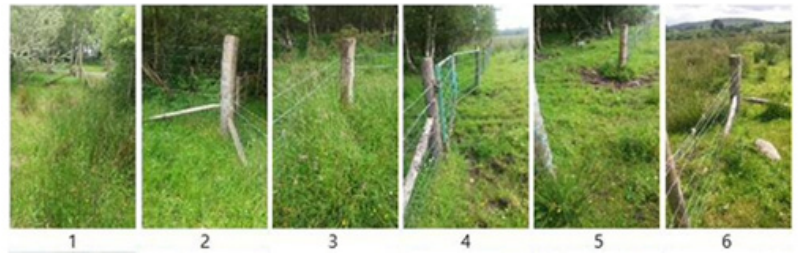

Fig 5: Imagery associated with various points along part of the boundary.

To have a sense of the positional accuracy, the boundary coordinates collected were connected and turned into polygons and then compared with a digitisation of a 1:1000 MasterMap excerpt (Fig 4). This revealed a minimum distance difference of around $0.5 \mathrm{~m}$ (especially where the boundary was easily accessible) and a maximum difference of about $7 \mathrm{~m}$

\section{Socio-technical Dimensions}

Technology is not neutral - it has a socio-technical context that cannot be ignored. Crofting is a way of life rooted in the past and linked to eviction of tenant farmers in the Scottish Highlands during the 18th and 19th Centuries. Some Crofters see technology as an invasion of their privacy. Others follow the ways of Crofting in order to live 'off grid', even where this tends to stand in the way of economic and social development (Thomas, 2005). For them, technology is an unwelcome intrusion.

Use of the technology led to discussion of numerous concerns about current crofting legislation and the future of crofting. One crofter revealed that many 'crofters' in the area have no intention of adopting an actual crofting life- style and might (mistakenly) fear the technology might reveal as much. Some people jump through the many legal 'loopholes', buying tenancy over croft land and then building houses that are often too big in size, and within the sightline of hills in the distance or build a second house on a croft - none of which is normally allowed. Certain rules, such as keeping a minimum number of sheep (11), are adhered to as mere formalities.

One crofter was concerned that the technology would reveal their bad practices. They pointed out a nearby sliver of 'no man's land' as well as a neighbour's fence being put up a few metres from the original boundary wall in order to avoid having to maintain the wall. Such issues are not resolvable by any technological solution. Legal frameworks must resolve such issues since there is more complexity to a croft boundary than the simple measurement of the position of markers, which descriptions could help clarify.

The Scottish Crofting Federation (2009) stresses that crofters often tend to not be so fixated on their boundaries and forcing boundary delineation would inevitably lead to new disputes; the current croft registration process does not include any efficient or low-cost mechanism for dispute resolution - the only option is an expensive court settlement. Establishing boundaries in a manner that captures all the complexities surrounding them would require a more participative mapping procedure, preferably as a community.

Two of the participants saw the benefits of CroftCappture in terms of reducing costs and effort in getting their crofts mapped (e.g. one participant took 1 hour and 30 minutes to map their croft, as opposed to perhaps weeks of correspondence with the Crofting Commission to get the mapping right), and looking at its functionality, the application can be considered a way of clarifying any vagueness surrounding boundaries. However, for CroftCappture to be of any use, the Crofting Commission itself must be willing to accept croft evidence that does not meet their expectations of accuracy associated with survey quality technologies.

\section{Discussion and Conclusion}

The positive evaluation of CroftCappture by crofters in terms of usability and functionality shows that crofters would be capable of independently mapping their crofts using a smartphone. In general, collecting VGI by individuals through smartphones for land registration purposes is very feasible. Positional accuracy-wise, an error of up to $7 \mathrm{~m}$ in real-life conditions is quite considerable. The $3.14 \mathrm{~m}$ RMSE calculated based on an initial test only accounted for points that were readily accessible. The positional error could be reduced by once again, providing better instructions (in the form of a trial run or video), encouraging users to walk as closely to their boundaries as they can. The recent introduction of Galileo, a European GNSS, will further increase this accuracy (GSA, 2014). Feeding collected boundaries into a desktop GIS revealed many sliver polygons and overlaps. Participant A mentioned how difficult it is for the Crofting Commission to deal with such issues. In 
countries where no land register is in place, this drawback would most probably be overlooked, as the technology still manages to provide some form of land boundary information (i.e. it is 'fit-for-purpose'; McLaren, 2011b; Moreri et al., 2016).

While photographs and descriptions could well enrich the information provided about crofts, certain crofters might see no added benefit in including these. Some crofters may either not care about the history of their croft, or simply not know much about it. In spite of this, they may still be interested in simply the boundary recording functionality of CroftCappture as a low-cost method of obtaining geospatial information on their croft and such information can be used in other contexts (calculating area, recording plant health, calculating stocking levels, identifying fence and boundary repairs, for example). The descriptions and photographs could serve as a way to clarify any boundary complexities, such as markers that are inaccurately placed or boundaries that were never really fixed. Capturing this complexity could address some of the Scottish Crofting Federation's concerns. In societies where boundaries are vague by nature - such as the crofting community - and/or the tenure relationships are such that representing them by photographs or descriptions are accepted, smartphone-based VGI could be very useful.

Despite legislation and organisational practices being a hindrance, governments are slowly accepting VGI as a valuable information source (Haklay et al., 2014). From the public's side, however, while true crofters (i.e. those still adhering to the traditional crofting lifestyle) seem to welcome smartphone technology to record their tenure and appreciate the participatory nature of it, those using 'crofting' as a term to cover up simply wanting to own land and build houses in rural areas are very likely to be suspicious of it, probably raising concerns about their privacy. It would in that case be this group of crofters who could hamper the acceptance of smartphone-based VGI in croft registration.

In the case of the crofting community and the Crofting Commission, the results of this study suggests that there is a positive outlook for the introduction of smartphonebased VGI for croft registration, especially because of its ability to capture boundary complexities inherent to crofts and the fact that it involves a participatory mapping process. Some shortcomings could be addressed if the app was used as part of a community mapping exercise, which would give the opportunity for dialogues between crofters to settle any disputes that may arise. In that sense, a fusion of VGI approaches would be the ideal solution. In certain countries where the STDM is gaining recognition this approach is already being implemented, but where LASs have just departed from standards of high accuracy and pure geometry, and authorities are just starting to learn that a boundary is more than simply a line, it will take more time.

\section{Further Research}

CroftCappture could be made more user-friendly.through the recording of voice coupled with text-to-speech recog- nition in order to reduce the time in gathering descriptions, while the possibility to recognise previously recorded boundary sections and only record new ones would help eliminate the need to walk along a shared boundary twice. Alternatively, a shared boundary could still be recorded from both sides, but the formed sliver in between could be eliminated via the skeletonisation of that sliver, during which the medial axis of the polygon is found based on its interior Delaunay triangulation. This medial axis would then form the boundary between two crofts (Bader and Weibel, 1997; Haunert and Sester, 2008). Furthermore, a map-matching technique similar to what is presented in Li et al. (2005) could be introduced that would intelligently snap the device's current location to the most likely feature on MasterMap. Note that increasing the application's sophistication with more functionality may reduce its usability (Harrison et al., 2013), which may be attributed to a more cluttered and less intuitive user interface or higher complexity in the tasks the user has to carry out. Finding that balance between sophistication and usability is where the real challenge lies in the development of technology for the public.

Looking at the outcomes from a different angle, an application could be designed based on CroftCappture as a mobile GIS-based storytelling platform. Research has already been conducted on using Android applications to guide tourists through Edinburgh via a storyline ( $\mathrm{Zhu}$, 2013; Ray, 2014), but a location-aware application to allow users to tell their own stories based on their location and movement does not yet seem to exist.

Another interesting tangent would be to use an adapted version of CroftCappture as a reporting tool for malpractice in land matters. One participant described plots of 'no man's land', practices employed to avoid maintenance costs, houses not conforming to true crofting... A location-aware mobile system that assures the privacy of its users would encourage reporting and may help in eradicating or reducing legal violations and disputes. Rahmatizadeh et al. (2016) already propose using VGI for the review and correction of land-related information.

\section{References}

BADER, M. and WEIBEL, R. (1997) Detecting and resolving size and proximity conflicts in the generalization of polygonal maps. Paper presented at the 18th International Cartographic Conference, Stockholm, Sweden, 23-27 June.

BENNETT, R. M., VAN GILS, H., ZEVENBERGEN, J., LEMMEN, C. and WALLACE, J. (2013) Continuing to bridge the cadastral divide. Paper presented at the Annual World Bank Conference on Land and Poverty, Washington, DC, United States of America, 8-11 April.

ClEGG, P., BRUCiATELli, L., DOMINGOS, F., JONES, R. R., DE DONATIS, M. and WILSON, R. W. (2006) Digital geological 
mapping with tablet PC and PDA: a comparison. Computers \& Geosciences. 32, pp. 1682-1698. doi: 10.1016/j.cageo.2006.03.007

DALE, P. F. and MCLAUGHLIN, J. D. (1988) Land information management: an introduction with special reference to cadastral prob- lems in Third World countries. Wotton-under-Edge: Clarendon Press.

DE VRIES, W. T., BENNETT, R. M. and ZEVENBERGEN, J. (2016) Toward responsible land administration. IN: ZEVENBERGEN, J., DE VRIES, W. T. and BENNETT, R. M. (Eds.) Advances in responsible land administration. Boca Raton, FL: CRC Press.

DUCHATEAU, R. (2016) Evaluating smartphone-based volunteered geographic information for land registration: the case of the Scottish crofting community. Part II: supporting document. Thesis (MSc). The University of Edinburgh.

FEDER, G. and NISHIO, A. (1999) The benefits of land registration and titling: economic and social perspectives. Land Use Policy. 15(1), pp. 25-43.

GSA (2014) 'The results are in: Galileo increases the accuracy of location based services'. European Global Navigation Satellite Systems Agency. 27 October. Available from:

http://www.gsa.europa.eu/news/results-are-galileoincreases-accuracy-location-based-ser- vices [Accessed 27/06/2016].

HAKLAY, M., ANTONIOU, V., BASIOUKA, S., SODEN, R. and MOONEY, P. (2014) Crowdsourced geographic information use in government. Washington, DC: The World Bank.

HARRISON, R., FLOOD, D. and DUCE, D. (2013) Usability of mobile applications: literature review and rationale for a new usability model. Journal of Interaction Science. 1(1). doi: 10.1186/2194-0827-1-1

HAUNERT, J.-H. and SESTER, M. (2008) Area collapse and road centerlines based on straight skeletons. Geoinformatica. 12, pp. 169- 191 . doi: 10.1007/s10707-007-0028-X

INDUFOR (2014) Analysis on the costs of securing communal land rights: new technologies and approaches offer potential for scaling up prepared for the rights and resources initiative. Helsinki: Indufor.

LI, J., TAYLOR, G. and KIDNER, D. B. (2005) Accuracy and reliability of map-matched GPS coordinates: the dependence on terrain model resolution and interpolation algorithm. Computers \& Geosciences. 31(2), pp. 241-251. doi: 10.1016/j.cageo.2004.06.011

MCLAREN, R. (2011a) Crowdsourcing support of land administration - a partnership approach. IN: SCHENNACH, G. (Ed.) Cadastre

2.0. Proceedings: International FIG Symposium \& Commission 7 Annual Meeting. Copenhagen: International Federation of Sur- veyors.

MCLAREN, R. (2011b) Crowdsourcing support of land administration - a new collaborative partnership between citizens and land pro- fessionals. Copenhagen: International Federation of Surveyors.

MCLAREN, R. (2013) Technology to promote transparency around land acquisitions. Hemel Hempstead: Evidence on Demand. MCLAREN, R. (2014) Can the MapMyRights intitiative be a game changer? Paper presented at FIG Congress: Engaging the Challenges- Enhancing the Relevance, Kuala Lumpur, Malaysia, 16-21 June.

MORERI, K., FAIRBAIRN D. and JAMES, P. (2015) Technological solutions for citizens' participation into cadastral mapping. Paper presented at the 27th International Cartographic Conference, 16th General Assembly, Rio de Janeiro, Brazil, 23-28 August.

MORERI, K., FAIRBAIRN D. and JAMES, P. (2016) Establishing the quality and credibility of volunteered geographic information in land administration systems in developing countries. Poster presented at GIS Research UK 2016, Greenwich, United Kingdom, 30 March-1 April.

NICHOLS, S. E. (1993) Land registration: Managing information for land administration. Thesis (PhD). University of New Brunswick.

PRASTOWO, H. (2011) Performance evaluation of digital pen for capturing data in land information systems (LIS). Thesis (MSc). The International Institute for Geo-information Science and Earth Observation.

RAHMATIZADEH, S., KALANTARI, M., RAJABIFARD, A., HO, S. and DANESHPOUR, A. (2016) How VGI intersects with land

administration. Paper presented at the 3rd Annual Conference of Research@Locate, Melbourne, Australia, 12-14 April.

RAY, D. (2014) Storytelling in space and time. Thesis (MSc). The University of Edinburgh.

SCOTTISH CROFTING FEDERATION (2009) SCF response to the Crofting Reform (Scotland) Bill consultation May 2009. Available from: http://www.crofting.org/ uploads/news /dCRB_response_-_SCF.pdf [Accessed 25/07/2016].

THE SCOTTISH GOVERNMENT (2009) Draft Crofting Reform (Scotland) Bill consultation paper. May 2009. Edinburgh: The Scottish Government.

THOMAS, D. A. (2005) Development, "culture", and the promise of modern progress. Social and Economic Studies. 54(3), pp. 97-125. UNECE (2005) Land administration in the UNECE region. Development trends and main principles. Geneva: UNECE.

UN-HABITAT (2012) Designing a land records system for the poor. Nairobi: UN-HABITAT.

VAN ELZAKKER, C. P. J. M. (2004) The use of maps in the exploration of geographic data. Thesis $(\mathrm{PhD})$. The International Institute for Geo-information Science and Earth Observation.

ZHU, Q. (2013) Story telling in space and time: an Android application for ghost tour in Edinburgh using 
smart phones. Thesis (MSc). The University of Edinburgh. 